\title{
The Effectiveness of Brainstorming and Brainwriting Strategies to Teach Writing for Students with High and Low Interest in the Academic Year of 2019/2020
}

\author{
Aditya Astu Bhairawa ${ }^{1}$, Abdurrachman Faridi ${ }^{2}$, Rudi Hartono ${ }^{2}$ \\ ${ }^{1}$ Student of English Department Department of Semarang State University \\ ${ }^{2}$ Lecturer of English Education Department of Semarang State University \\ ${ }^{3}$ Lecturer of English Education Department of Semarang State University \\ Corresponding E-mail: aditastu1993@gmail.com
}

DOI: 10.29322/IJSRP.11.01.2021.p10997

http://dx.doi.org/10.29322/IJSRP.11.01.2021.p10997

\begin{abstract}
The aim of this research is to investigate how effective was brainstorming and brainwriting strategy to teach writing to students with different interest. This paper showed that the result of experimental research on writing skills to students with high and low interest at MTs Ma'arif Nu 1 Kembaran. A 2x2 factorial design of experimental research was used to collect the data from 60 students which divided into two groups; they were experimental group one and experimental group two. They were treated with different strategies: Brainstorming and strategy and Brainwriting strategy. The instrument of this research was observation checklist, questionnaire, and test (pre-test and post-test). The data was analysed using ANOVA to prove the hypothesis. The result showed that brainwriting was more effective to teach writing to students with high and low interest. Based on the analysis of ANOVA, there were no interaction among strategies, writing skills and students' interest.
\end{abstract}

Key words: Brainstorming, Brainwriting, Writing Skills, Students' Interest

\section{INTRODUCTION}

English is an international language which has been spoken by many countries in the world. Englsih seems to be the most important language in many aspects such as entertainment, law, economics, business, tourism, politic, education, and other activites. It means that English has become a lingua franca. Srinivas (2019) defnes a lingua franca as a language that is used to communicate among different people all over the world.

Writing is one of the four skills in learning language which have important parts in communication. According to Harmer (1998) said that "By far the most important reason for for teaching writing, of course, is that it is a basic language skill, just as important as speaking, listening, and reading. Writing skills is needed from elementary school until university level to university level which have purpose to tell something that is abstract in writers' mind then express in in written form. Moreover, Phelps (2001) stated that writing is an activity in processing, interpreting, and evaluating information and putting in a logical, coherent, and well-responded management.

Many students still can't be able to create a meaningful writing. Harris (1993) stated that writing is regarded as the most complex one compared with the other three skills because the relationships between sentences operate at several levels. So that, the students should pay attention of writing new ideas such as content, organization, vocabulary, language use, and mechanic.

Writing becomes one of the lessons which are not mastered by the students in MTs Ma'arif NU 1 Kembaran at eight grades in academic year 2019/2020. The researcher found several problems faced by the students which related to writing skills. Based on observation activity, this condition appeared in several problems. The first problems faced by the students are (1) students have difficulties in using appropriate grammar, (2) the lack of students' vocabulary, (3) spelling in writing new idea, (4) students' attention and participation in classroom in low.

Based on the problems in teaching and learning above, it is necessary to apply an appropriate strategy in learning English Language. By using the appropriate strategy, it can make the students feel free to express their ideas. Every teacher has different style of teaching which facilitate the storage, retrieval,or use of the new language. Wilson (2013) stated that brainwriting strategy is a technique for rapidly generating ideas by asking participants to write their ideas on a paper and exchanging written ideas. It helps the students associate ideas, write freedomly, and make connection between each ideas. Brainwriting is a modificaton from 
brainstroming. It is a group or an individual creativity method in which attempts to determine a definiteconclusion for a particular problems by obtaining information in form of a list of ideas that are contributed by the members Rowan (in Almashari, 2015).

Based on the background above, this study is aimed to find out the following research problems:

1. How are the interaction among brainwriting strategy, brainstorming strategy, and the students interst strategy to teach writing to the students?

2. How are the comparison between pre-test and post-test in teaching writing using brainstorming strategy to the students with high interest?

3. How are the comparison between pre-test and post-test in teaching writing using brainstorming strategy to the students with low interest?

4. How are the comparison between pre-test and post-test in teaching writing using brainwriting strategy to the students with high interest?

5. How are the comparison between pre-test and post-test in teaching writing using brainwriting strategy to the students with low interest?

6. How are the comparison between pre-test and post-test in teaching writing using brainstorming strategy to the students with high and low interest?

7. How are the comparison between pre-test and post-test in teaching writing using brainwriting strategy to the students with high and low interest?

8. How are the comparison between pre-test and post-test in teaching writing using brainstorming strategy and pre-test and post-test in teaching writing using brainwriting strategy to the students with high interest?

9. How are the comparison between pre-test and post-test in teaching writing using brainstorming strategy and pre-test and post-test in teaching writing using brainwriting strategy to the students with low interest?

Brainstorming activity is used to get the students' ideas based on their prior knowledge about the topic. During the process of brainstorming, the students will be divided into several groups. The entire group becomes able to know about another commitment towards the topic. Brainstorming activity is used to get the students' ideas based on their prior knowledge about the topic. During the process of brainstorming, the students will be divided into several groups. The entire group becomes able to know about another commitment towards the topic. Brainstorming is a strategy used to encourage individuals to generate ideas and come up with a list of possible solutions to certain problem (Salem, 2011).

Brainstorming technique was popularized by Alex Osborn. There are some rules that should be taken such as no criticism of ideas, building on what others have suggested, strange and wild area accepted, and welcoming the large quantities of ideas. Brainstorming is a strategy used to encourage individuals to generate ideas and come up with a list of possible solutions to certain problem (Salem, 2011). Brainstorming technique was popularized by Alex Osborn. There are some rules that should be taken such as no criticism of ideas, building on what others have suggested, strange and wild area accepted, and welcoming the large quantities of ideas.

Brainwriting is a part technique of brainstorming that use writing as the media, it tries to encourage the student within a group. This technique is also design to get a lot of ideas as the same as brainstorming. One of the famous strategies in brainwriting is 6-3-5 method. The process of that method involves the following steps: 6-3-5 means that 6 in group, 3 ideas in a round, and 5 minutes in a round. The process of that method involves the following steps:

1. $\quad$ Divide the participants into group of 6.

2. Each of participants stars with a prewritten brainwriting form. The problem to be solved is written in the top of form.

3. In the first round, the participants have five minutes to write three ideas in the form.

4. In the end of each round, the form is passed to the person on the right. As the next person get the form, the read all the ideas on the form and add the new three ideas. The ideas may be a new idea or a variation of ideas already written in the form. There is no talking or discussing during the round.

5. The process is complete when each participant gets his own form back, now filled up with many ideas.

6. The last step is to sort the ideas using clustering method.

During the process of this strategy, the participants are allowed to write a new idea, modify the previous ideas, adapt the previous ideas, or maybe combine the ideas. By using this strategy, the silent students get the advantages in the way that they have chance to express their ideas in written form.

\section{METHOD}

This research uses experimental research design. Brown $(2001 ; 294)$ defines an experiment as a process or study that result in the collection of the data. Usually, statistical experiments are conducted in situations in which researcher can manipulate the conditions of the experiment and control the factors. This research consists of one dependent variable, two independent variables, and moderator 
variable. Dependent variable is writing skills, two independent variables are brainstorming and brainwriting strategy, and moderator variable is students' interest. The subject of the study is the students of MTs Ma'arif NU 1 Kembaran, while the object of the study is the students' writing skill. There are two experimental groups in this design; experimental group 1 that receive brainstorming as the treatment and experimental group 2 that receive brainwriting as the treatment. Both groups are given a pre-test and post-test. Observation checklist was used to know the condition of teaching and learning in the class, while questionnaire was used to know the interest of students in learning English. The method of analyzing the data were descriptive analysis and inferential analysis. ANOVA test was used to know whether the significant of variable was significant or not.

\section{FINDING AND DISCUSSION}

Before the researcher giving treatment to the class, the students are asked to do pre-test. In here, pre-test was used to determine whether the writing ability of the class the same or not. The students also asked to answer the questionnaire to know their level of interest in learning English. After that, the students got the treatment. Experiment class one got the treatment by using brainstorming strategy while experiment class two got the treatment by using brainwriting strategy. Then the researcher gave post-test after the treatment are finished. The data showed that the significant value of pre-test is higher than $0.05(0.200,0.146,0.200,0.080>0.05)$. It means that the data in pre-test is distributed normally. While in post-test, that the significant value of post-test is higher than 0.05 $(0.200,0.200,0.198,0.200>0.05)$. It means that the data in post-test is distributed normally. The Levane Statistics of pre-tests was 0.978 and significant value was more than $0.05(0.327>0.05)$, it means that the data in pre-test was homogeneous. While the Levane Statistics of post-tests 1.524 and significant value is more than $0.05(0.222>0.05)$, it means that the data in post-test was homogeneous.

The first research question was to find out whether there is a significant interaction among writing skills, strategies, and students' writing interest or not. According to ANOVA test, the significant value was 0.174 (more than 0.05). Therefore $\mathrm{H}_{\mathrm{O}}$; there is a significant interaction among writing skills, strategies, and students' writing interest, is rejected.

The second hypothesis is brainstorming strategy is effective to enhance students writing skill with high interest in experiment class one. Based on the data, it can be showed that the mean score of post-test data (80.45) was higher than pre-test (63.45) in experimental class one with high interest. From the table of paired sample t-test, the significant value was 0.000 . It shows that $0.000<0.05$. The second hypothesis is accepted.

The third hypothesis is brainstorming strategy is effective to teach writing to students with low interest. Based on the result, brainstorming strategy is also effective to use in teaching writing to students with low interest. The pre-test score of experimental class one with low interest (52.27) is lower than the post-test score of experimental class one with low interest (68.00). From table of paired sample t-test, it can be seen that the significant value is 0.000. it was less than 0.05 . The third hypothesis is accepted.

The fourth hypothesis is brainwriting strategy is effective to teach writing to students with high interest. From the post-test data, it showed that the mean score of experimental class two with high interest students (80.75) are higher than the mean of pre-test score of experimental class two with high interest students (64.57). It can be seen from table of paired sample of t-test, the significant value is 0.000 and it was less than 0.05 . The fourth hypothesis is accepted.

The fifth hypothesis is brainwriting strategy is effective to teach writing to students with low interest. Based on the data, the mean of pre-test score of experimental class two with low interest (53.59) is lower than the mean score of post-tests of experimental class two with low interest (70.90). As stated in table of paired sample t-test, the significant value is 0.000 . it was less than 0.05 . The fifth hypothesis is accepted.

The sixth hypothesis is there is an interaction between brainstorming strategy and students' interest (high and low) in teaching writing to the students. The mean score of students with high interest is 17.300 and the mean score of students with low interest is 15.725. As stated in table of independent sample tests of experimental class one, the significant value is 0.511 and it was more than 0.05 . The sixth hypothesis is rejected.

The seventh hypothesis is there is an interaction between brainwriting strategy and students' interest (high and low) in teaching writing to the students. From the mean score of experimental class one with high interest (80.45) is lower than the mean score of experimental class two with high interest (80.75). The significant value in table of independent sample tests of experiment class two is 0.797. It was more than 0.05 . The seventh hypothesis is rejected.

The eighth hypothesis is brainwriting is more effective than brainstorming strategy to teach writing for students with high interest. From the mean score of experimental class one with high interest (80.45) is lower than the mean score of experimental class two with high interest (80.75). The eighth hypothesis is accepted. 
The ninth is brainwriting is more effective than brainstorming strategy to teach writing for students with low interest. Form the mean score of experimental class two with low interest (70.90) is higher than the mean score of experimental class one with low interest (68.00). The ninth hypothesis is accepted.

\section{CONCLUSION}

The result aimed to find out whether brainstorming and brainwriting strategies were effective in teaching writing for students with high and low interest. Based on the result above, some conclusion can be drawn. First, students' interest is influencing in teaching writing using brainstorming and brainwriting strategies. Second, brainwriting strategy is more effective that brainstorming strategy. This is proven by the significant in improving students writing skills of students with high and low interest. However, there was no interaction found between strategies, writing skills, and students' interest.

\section{REFERENCES}

Alshammari, M. K. (2015). Effective Brainstorming in Teaching Social Studies for Elementary School. American International Journal of Contamporary Reseach,5(2). http://www.aijcrnet.com/journals/Vol_5_No_2_April_2015/9.pdf

Brown, H. (2001). Language Assasment (Principles andClasssroom Practices) Longman: Pearson Education Limited.

Harris, John. (1993). Introducing Writing. London: Penguin English.

Harmer, J. (1998). How to Teach English (An Introduction to The Practice of English Language teaching. Longman: Pearson Education Limited.

Phelps, M. 2001. The Power of Strategy Instruction. Available on http://ninchy.org.research/ee/learningstrategies.

Salem, Ibnian Khalaf Saleh. (2011). Brainstorming and Essay Writing in EFL Class. Theory and Practice in Language Studies. Volume 1. No 3. Pp 263-272. Doi: $10.4304 /$ tpls.1.3.263-272

Srinivas Rao, Parupalli. (2019). The Role of Englsih As A Global Language. Research Journal of English (RJOE), Volulme 4. Issue_1. Pp 65-79. Doi: $\underline{10.33329 / i j e l r .64 .196}$

Wilson, Chauncey. (2013). Brainstorming and Beyond A User-Centered Design Method. UK: Elsevier 